\title{
Rezyliencja jako paradygmat bezpieczeństwa w czasach przewlekłych kryzysów ${ }^{1}$
}

\begin{abstract}
Streszczenie: W dobie przewlekłych i cyklicznych kryzysów takich jak epidemie, wzmożone ruchy migracyjne, czy zmiany klimatyczne rezyliencja stała się atrakcyjnym i zyskującym na popularności podejściem do bezpieczeństwa. Dostarcza ona inspiracji do zmiany sposobu myślenia o zarządzaniu kryzysowym, rozproszeniu odpowiedzialności za bezpieczeństwo czy temporalności zagrożeń. Rezyliencja skupia uwagę na wspólnotowych i indywidualnych mechanizmach radzenia sobie z kryzysami, adaptacji do ciężkich warunków oraz powrocie do jakiejś formy normalnego stanu po okresie kryzysu. Celem artykułu jest przegląd i przybliżenie koncepcji rezyliencji, zaoferowanie syntezy obecnego rozumienia tej koncepcji oraz porównanie jej różnych inkarnacji w perspektywie nauk o polityce i bezpieczeństwie. Autor postuluje, iż rezyliecja jest obiecującym podejściem teoretycznym, i tym samym powinna być szerzej wykorzystywana $\mathrm{w}$ badaniach nad polskimi dyskursami i praktykami bezpieczeństwa.
\end{abstract}

Słowa kluczowe: rezyliencja, ryzyko, bezpieczeństwo, zarządzanie kryzysowe, COVID-19

\section{Wstęp}

$\Delta$ ktualnie dominujący paradygmat bezpieczeństwa został ukształtowany głównie Aprzez ataki terrorystyczne w Stanach Zjednoczonych i Europie w pierwszej dekadzie XXI wieku (Lund Petersen, 2008). Jest on oparty na zarządzaniu ryzykiem, skupiając się na możliwych do przewidzenia zagrożeniach i scenariuszach, które można kontrolować przy pomocy neoliberalnych technologii zarządzania ryzykowną przyszłością (Aradau, van Munster, 2011; Lund Petersen, 2008). W tym ujęciu, podmioty odpowiedzialne za bezpieczeństwo starają się zapobiegać atakom terrorystycznym, interweniować w sytuacji kryzysów finansowych, czy gwałtownych konfliktów przy pomocy szeroko rozumianych systemów wczesnego ostrzegania, które z dużą dozą prawdopodobieństwa są w stanie przewidzieć negatywne zdarzenia i umożliwić bezzwłoczną reakcję (Harff, Gurr, 1998; Stepka, 2016).

Co się jednak dzieje, gdy środowisko bezpieczeństwa zaczyna nasycać się przewlekłymi i cyklicznymi kryzysami takimi jak kryzys klimatyczny czy pandemie, które widocznie wykraczają poza możliwości zarządcze lub nawet poznawcze człowieka? W jaki sposób system może przetrwać w sytuacji, gdy kryzysy zaczynają wymykać się istniejącym możliwościom decyzyjnym, paradygmatom zarządzania kryzysowego i techno-

${ }^{1}$ Artkuł powstał w wyniku realizacji grantu Narodowego Centrum Nauki nr 2015/19/N/HS5/01229, oraz projektu pt. „Rezyliencja (resilience) jako paradygmat bezpieczeństwa w czasach pandemii COVID-19. Przypadek Rzeczypospolitej Polskiej” finansowanego ze środków konkursu SocietyNow!\#1 w ramach programu Inicjatywa Doskonałości w Uniwersytecie Jagiellońskim. 
logiom antycypacyjnym, mającym na celu przygotować społeczeństwa na najbardziej prawdopodobne zagrożenia? W odpowiedzi na tego typu pytania środowiska naukowe oraz polityczne zaczęły wprowadzać do dyskursu akademickiego i polityk publicznych koncepcję rezyliencji (ang. resilience), często ujmowaną w kategoriach swoistego panaceum na skrajną niepewność oraz przewlekłe i trudne do przewidzenia wyzwania dla bezpieczeństwa (Cavelty, Prior, 2013). W ten sposób, elementy „myślenia rezyliencyjnego" nasyciły już w pewnym stopniu doktryny bezpieczeństwa takich krajów jak Stany Zjednoczone, czy Singapur oraz organizacji międzynarodowych w tym Unii Europejskiej, NATO, czy Organizacji Narodów Zjednoczonych (Cavelty, Prior, 2013; Juncos, 2017; Prior, 2017).

Rezyliencja powszechnie definiowana jest jako umiejętność przetrwania jednostek lub systemów (np. ekologicznych czy gospodarczych) w szybko zmieniającym się świecie, naznaczonym niezwykle złożonymi i niemożliwymi do przewidzenia kryzysami i napięciami (Bourbeau, 2013, s. 5-7). W swojej istocie, rezyliencja jest koncepcją funkcjonującą na pograniczu dziedzin i dyscyplin naukowych, inspirującą badania z zakresu ekologii, psychologii, socjologii czy politologii i nauk o bezpieczeństwie (Zebrowski, 2013). W ten sposób w ujęciu multidyscyplinarnym, rezyliencja nabierała wiele różnych znaczeń, od sprężystości materiałów takich jak przędza czy stal, po zaradność ludzi i wytrzymałość systemów społecznych i politycznych w dobie kryzysu (Olsson i in., 2015, s. 1-2). W powszechnym rozumieniu uważa się, że rezyliencja polega na zdolności radzenia sobie z zakłóceniami, adaptacji do ciężkich warunków oraz powrotem do jakiejś formy normalnego stanu po okresie kryzysu, który naruszył pożądane status quo (Norris $\mathrm{i}$ in., 2008, s. 130).

Rezyliencja jest koncepcją wewnętrznie zróżnicowaną, czy jak sugeruje Gruszczak, nawet gruntownie kontestowaną i dlatego wymaga głębszego zastanowienia się nad jej najbardziej właściwym tłumaczeniem i użyciem w polskim dyskursie naukowym i publicznym (Gruszczak, 2016, s. 8). W piśmiennictwie polskojęzycznym nie było jeszcze szerszych prób przeszczepienia tego pojęcia do dyskursu politologicznego lub nauk o bezpieczeństwie, dlatego też nie istnieje termin, który byłby szeroko akceptowalny przez środowisko akademickie. W tym artykule wykorzystywany jest, być może mało zgrabny, ale najbardziej upowszechniony w socjologii, psychologii i pedagogice zwrot „rezyliencja” (Dacko, Dacko, 2018; Drobniak, 2018; Pyka, 2018). Zdaniem autora, ten termin jest aktualnie najlepszą próbą ujęcia tego bardzo szerokiego konceptu. Nie ogranicza jego interpretacji do popularnych tłumaczeń jak „odporność” czy „sprężystość”, które niepotrzebnie redukują jego znaczenie i nie odzwierciedlają wewnętrznej złożoności tej koncepcji (Grzegorzewska, 2013).

Niniejszy artykuł ma charakter przeglądowy, a jego celem jest przybliżenie koncepcji rezyliencji, usystematyzowanie wiedzy na jej temat, oraz przeprowadzenie dyskusji nad jej złożonością i użytecznością w kontekście nauk o polityce i bezpieczeństwie. Literatura poświęcona przypadkowi Polski i polskiemu podejściu do rezyliencji jest niezwykle skromna. Dlatego, poprzez ten artykuł autor postuluje wyraźniejsze włączenie rezyliencji do badań nad polskimi politykami, dyskursami i praktykami bezpieczeństwa, przede wszystkim w kontekście najnowszych zmian w strategii bezpieczeństwa RP, skuteczności reagowania kryzysowego, czy łagodzenia skutków pandemii COVID-19. Struktura artykułu oparta jest na następujących sekcjach. W pierwszej części artykułu dokonany 
został przegląd rozwoju rezyliencji z uwzględnieniem kluczowych wątków w dyskusji nad jej naturą i zastosowaniem w różnych dyscyplinach. W kolejnej sekcji artykułu przeprowadzona została dyskusja nad rezyliencją jako paradygmatem bezpieczeństwa ze wskazaniem na jej najważniejsze elementy i różnice w odniesieniu do istniejących sposobów myślenia o bezpieczeństwie. W tej sekcji artykułu, autor odwołuje się do rezyliencyzmu jako ramy analitycznej oraz zestawia różne typy rezyliencji analizując wewnętrze zróżnicowanie w rozumieniu tej koncepcji. W trzeciej i ostatniej sekcji artykułu zaprezentowane zostały wnioski końcowe wraz z krytyczną refleksją nad rezyliencją w ujęciu teoretycznym, jak i praktycznym.

\section{Czym jest rezyliencja?}

Współczesne rozumienie rezyliencji zostało w znacznej mierze ukształtowane przez ekologię i badania nad równowagą i stabilnością ekosystemów oraz psychologię, pedagogikę i szereg prac poświęconych adaptacji i odporności psychicznej (Lucini, 2014, s. 32-53). W ekologii, rezyliencja symbolizuje nowe otwarcie dla badań nad stabilnością i przetrwaniem ekosystemów. Za twórcę i czołowego promotora rezyliencji ekologicznej uznaje się C. S. Hollinga, który w 1973 roku zakwestionował tradycyjne pojmowanie równowagi, polegającej na bezwzględnej stabilności systemu w obliczu wydarzeń kryzysowych, naruszających pożądany stan (Holling, 1973). Uważał on, iż w rezultacie ciągłych lub incydentalnych zakłóceń system może utracić równowagę, jednak nadal utrzymywać swoje podstawowe cechy i funkcjonalność (Holling, 1973, s. 2). Właściwość, która pozwala na utrzymanie takiego stanu określił mianem rezyliencji. Według Hollinga, rezyliencja opiera się na trwałości relacji układów w określonym systemie, stanowiącej miarę zdolności tych układów do absorpcji zmian wpływających na jego stan oraz zmienne, które nim sterują (Holling, 1973, s. 27). W związku z tym ekologiczne podejście do rezyliencji proponuje postrzeganie jej jako zdolności określnego systemu (np. ekologicznego czy społecznego) do absorbowania wstrząsów i przetrwania w często dynamicznie zmieniających się i przez to niepewnych warunkach kryzysowych (Gunderson, 2000, s. 433).

W psychologii, rezyliencja powszechnie definiowana jest jako cecha osobista lub proces związany z pozytywną adaptacją w kontekście znacznych przeciwności losu, traumy, tragedii, zagrożeń lub innego źródła stresu (Bonanno, 2004, s. 20-21). W takim ujęciu, rezyliencja często wykorzystywana jest w badaniach nad reakcjami jednostek na potencjalnie traumatyczne zdarzenia związane $\mathrm{z}$ naruszeniem ich podstawowych cech i możliwości funkcjonowania w systemie społecznym (Fletcher, Sarkar, 2013, s. 15). W niektórych kręgach, przede wszystkich związanych z psychologią społeczną i socjologią, dyskusja nad rezyliencją skupiła się na grupach społecznych i wspólnotowym wymiarze radzenia sobie w sytuacjach kryzysowych (Berkes, Ross, 2013). Pozwoliło to na uwzględnienie roli kapitału społecznego, czy praktyk społecznych (np. grup wsparcia), pozwalających jednostkom na złagodzenie negatywnych konsekwencji zdarzeń kryzysowych i powrót do zdrowia (Aldrich, Meyer, 2015). W tym duchu powstała literatura skupiająca się, na tzw. rezyliencji wspólnotowej (ang. community resilience), rozumianej jako zdolność członków określonej wspólnoty do podejmowania przemyślanych 
i istotnych działań o charakterze zbiorowym, w celu złagodzenia niepożądanych skutków kryzysów i powrotu do takiego stanu, który pozwoli na bezpieczny i zrównoważony rozwój tejże wspólnoty (Paton, Johnston, 2001, s. 273).

Wymiar wspólnotowy szybko stał się jednym z najbardziej dynamicznie rozwijających się nurtów w badaniach rezyliencyjnych. Podejście to wychodzi z założenia, że „całość jest czymś więcej niż sumą jej składników” wskazując, iż zbiór jednostek o wysokiej rezyliencji nie gwarantuje powstania społeczności, która jest w stanie utrzymać swoje podstawowe struktury i funkcje w sytuacjach kryzysowych (Berkes, Ross, 2013). Dlatego wspólnotowe rozumienie rezyliencji, ujmuje ją w kategoriach ciągłego procesu pozwalającego na wspólne wzmacnianie się jednostek, poszczególnych podsystemów i zdolności adaptacyjnych wspólnoty, która w rezultacie jest w stanie uzgodnić i wyegzekwować pozytywną trajektorię działań (Norris i in., 2008, s. 131). W tym ujęciu mechanizmy społeczne, takie jak solidarność, wsparcie czy spójność, pozwalają na nabycie i utrzymanie niezbędnej elastyczności systemu, która z kolei umożliwia efektywne wykorzystanie jego zasobów materialnych, społecznych czy kulturowych w obliczu kryzysu (Walsh-Dilley, Wolford, 2015). Tak rozumiany wspólnotowy wymiar rezyliencji silnie zainspirował szereg badań nad rolą elastyczności systemów społecznych, ich gotowością na kryzysy czy umiejętnościami adaptacyjnymi w obliczu zagrożeń, otwierając tym samym dyskusję nad potencjalnym wykorzystaniem rezyliencji jako swoistego paradygmatu bezpieczeństwa (Bourbeau, 2015).

\section{Rezyliencja i rezyliencyzm w rozważaniach nad bezpieczeństwem}

Rezyliencja jako paradygmat bezpieczeństwa jest mocno zakorzeniona w dyskursie naukowym związanym z badaniami nad ryzykiem i zarządzaniem kryzysami i katastrofami (Brassett i in., 2013). Istotnie, ryzyko oraz rezyliencja mają wiele punktów wspólnych. Rezyliencja, podobnie jak ryzyko, odbiega od myślenia o zagrożeniach w kategoriach wróg-przyjaciel, dobrze rozpoznanych, często egzogennych. Zamiast tego, skupia swoją uwagę na wyzwaniach dla bezpieczeństwa, które mają charakter rozproszony, hybrydowy, usieciowiony, niepewny i przez to wymagający ciągłego rozpoznania, oceny i zarządzania (Dunn Cavelty i in., 2015). Tym samym, ryzyko i rezyliencja w swoim podejściu do bezpieczeństwie mocno wybiegają w przyszłość, skupiając swoje działania na „wyobrażaniu sobie” potencjalnych zagrożeń i kształtując politykę bezpieczeństwa w oparciu o antycypację i łagodzenie skutków kryzysów (Aradau i in., 2008, s. 150). Mimo rzeczywistego zbliżenia konceptualnego oraz przenikania się wielu aspektów ryzyka i rezyliencji, należy wyodrębnić pewne elementy rezyliencji, które uprawniają do postrzegania jej w kategoriach osobnego paradygmatu bezpieczeństwa (Bourbeau, 2013; Zebrowski, 2015).

W paradygmacie bezpieczeństwa opartym na ryzyku, niczym w „Raporcie mniejszości” Philipa K. Dicka, ,problemy są definiowane i rozwiązywane zgodnie z ich przewidywanymi przyszłymi konsekwencjami, niezależnie od tego, czy kiedykolwiek się zmaterializują czy nie" (Niemann, Schmidthäussler, 2014, s. 16). Wymaga to opracowania i wdrożenia technologii, które pozwalają obliczyć stopień prawdopodobieństwa tego, co może zaoferować przyszłość, w celu uniknięcia, kontrolowania i minimalizowania 
szkodliwych skutków potencjalnych zagrożeń (Aradau i in., 2008, s. 149). Z perspektywy polityki bezpieczeństwa przekłada się to na zdefiniowanie i skupienie się na takich kategoriach ryzyka, które będą mogły być „okiełznane” przez neoliberalne praktyki kontroli i nadzoru (Brassett i in., 2013, s. 223). W tym ujęciu bezpieczeństwo opiera się zasadniczo na zarządzaniu wersją przyszłości, która z dużą dozą pewności niesie za sobą niepożądane wydarzenia.

Rezyliencja także uznaje niepewność, złożoność i wysoką dynamikę środowiska bezpieczeństwa, lecz idzie jeszcze dalej, ujmując nadchodzące katastrofy jako coś, czego nie sposób kontrolować (Dunn Cavelty i in., 2015). Wildavsky, jeden z pierwszych badaczy rezyliencji w naukach społecznych, jasno wskazuje, że zarządcze podejście do ryzyka i antycypacja zagrożeń jest o tyle efektywną strategią podejmowania decyzji i tworzenia polityki publicznej, o ile możliwości technologiczne pozwalają na satysfakcjonującą ewaluację przyszłości (Wildavsky, 1988). Jednak w warunkach, w których środowisko bezpieczeństwa jest skrajnie dynamiczne i nieprzewidywalne, antycypacja zagrożeń i próby zarządzania ryzykiem dają złudne poczucie pewności i bezpieczeństwa w bardzo niepewnym świecie. W tej sytuacji Wildavsky proponuje zmienić podejście do tworzenia polityk publicznych i oprzeć je na budowaniu rezyliencji. Zamiast inwestować w działania zapobiegające np. jednemu najbardziej prawdopodobnemu kryzysowi, można rozproszyć zasoby, próbując zwiększyć wydajność i odporność systemu (np. społeczeństwa) jako całości (Wildavsky, 1988, s. 87-88).

Rezyliencja wyraźnie zmienia sposób myślenia o środowisku bezpieczeństwa. Prawdopodobieństwo pojawienia się kolejnych fal szoków i zakłóceń (zarówno endogenicznych, jak i egzogenicznych) jest niemożliwe do zmierzenia i obliczenia. Dlatego, kluczowym elementem w tym podejściu do bezpieczeństwa jest uznanie niepewności i nieuchronności nadchodzących wydarzeń i odejście od przekonania, że przyszłością można zarządzać, a kryzysom można całkowicie zapobiec (Dunn Cavelty i in., 2015, s. 9). Ciągłe zakłócenia systemu stają się nową normą dla życia społecznego, gospodarczego i politycznego. Dlatego rezyliencja proponuje rozbudowywać nie tyle zdolności prewencyjne, co szeroko rozumianą kulturę gotowości, opartą na centralnych i lokalnych (w tym oddolnych) mechanizmach zdolnych do absorpcji szoków i/lub adaptacji wrażliwych elementów systemu społecznego, gospodarczego czy politycznego (Adey, Anderson, 2012). W ten sposób, rezyliencja ma stanowić alternatywny model dla angażowania niepewności, podkreślając potrzebę , utrzymywania otwartych opcji” i ,oczekiwania na nieoczekiwane" (Brassett, Vaughan-Williams, 2015).

W centrum podejścia rezyliencyjnego, nie leży identyfikacja zagrożeń, lecz najsłabszych ogniw, czyli najwrażliwszych punktów systemu (Zebrowski, 2013, s. 166). Zgodnie z tą myślą, polityki bezpieczeństwa powinny koncentrować się nie tylko na wąsko rozumianej obronie przed zagrożeniami, lecz przede wszystkim na ciągłym zwiększaniu odporności i zdolności systemów do odtwarzania swoich zasobów i odzyskiwania funkcjonalności, jeżeli tylko zostały naruszone przez kryzys (Kaufmann, 2016, s. 102). W idealnym modelu rezyliencyjnym, każde ogniwo systemu powinno charakteryzować się autonomicznymi zdolnościami odpornościowymi i adaptacyjnymi. Niemniej jednak, wszystkie elementy systemu powinny być gotowe do udzielenia pomocy słabszym, bardziej wrażliwym ogniwom (przykładem takiego mechanizmu byłoby wykorzystanie sił zbrojnych do pomocy grupom wrażliwym w czasie kryzysu niemilitarnego) (Paton, 
Johnston, 2001, s. 274). W tym ujęciu, bezpieczeństwo ma charakter silnie usieciowiony, systemowy, połączony różnymi zależnościami, które mają na celu wspierać się nawzajem. Bazując na tym założeniu, najbardziej zaawansowane strategie zwiększania rezyliencji odchodzą od centralizacji bezpieczeństwa, obejmując szeroki katalog działań skupiających się na zwiększaniu odporności i wydajności społeczności lokalnych, edukacji, nauki i rozwoju, organizacji pozarządowych, czy administracji i usług finansowych (Kaufmann, 2013, s. 56).

W centrum rezyliencyjnego paradygmatu bezpieczeństwa znajdują się często marginalizowane lub wręcz pomijane elementy takie jak edukacja i umiejętność krytycznego myślenia, wydajność nauki i rozwoju, spójność i solidarność społeczna, czy pewność prawa (Kaufman, 2013). Oczywiście nie można stwierdzić, że te elementy są nieobecne w narodowych doktrynach bezpieczeństwa, jednak powszechnie nie znajdują się one w centrum narodowych strategii bezpieczeństwa i obrony. Rezyliencja, być może bardziej niż inne koncepcje, odwraca uwagę od tradycyjnego militarnego czy nawet państwo-centrycznego sposobu. Trudno odnaleźć odwołania do edukacji o zmianach klimatu, segregowania śmieci, umiejętności zarzadzania budżetem domowym, higieny czy wolontariatu jako istotnych elementów bezpieczeństwa państwa. W rezyliencyjnym sposobie myślenia tego typu aspekty są niezwykle istotne. W celu zwiększenia rezyliencji powinny stać się elementem o wiele bardziej docenionym w systemie bezpieczeństwa, niezależenie od jego poziomu, lokalnego, narodowego czy międzynarodowego.

$\mathrm{W}$ świetle powyższego, rezyliencja charakteryzuje się subsydiarnym podejściem do bezpieczeństwa. W widoczny sposób odchodzi od etatyzmu i w większym stopniu stawia obywatela i jego najbliższą wspólnotę w centrum polityki bezpieczeństwa. Obywatele nie są tylko obiektami, które powinny być chronione, ale stanowią istotną część zasobów budujących rezyliencję w wymiarze wspólnotowym, państwowym, czy nawet globalnym. Dunn Cavelty i jej współpracownicy zauważają, że rezyliencja dynamicznie przenosi odpowiedzialność w ramach systemu bezpieczeństwa, ,od rządu do gminy, od wymiaru krajowego do lokalnego, od służb bezpieczeństwa do obywatela (Dunn Cavelty i in., 2015, s. 7). W podejściu rezyliencyjnym oczekuje się od obywateli wysokiego stopnia gotowości, umiejętności szybkiej samoorganizacji w obliczu kryzysu, przede wszystkim w tym aspekcie, który jest narażony na jego negatywne skutki (Kaufmann, 2013). W duchu rezyliencji często inwestuje się w specjalne programy mające na celu podnieść gotowość i umiejętności radzenia sobie w obliczu kryzysów przez grupy wrażliwe (np. dzieci, seniorów). W związku z tym ,przeskalowaniem” bezpieczeństwa, strategie rezyliencyjne z przedmiotów polityk bezpieczeństwa tworzą jej podmioty, promując odpowiedzialność, samodzielność obywateli w obliczu kryzysu i równocześnie eliminując skrajne słabości systemu społecznego, wymagające pomocy i interwencji (Kaufmann, 2016, s. 103).

W naukach społecznych rezyliencja jest wewnętrznie zróżnicowana. Wprawdzie przeważająca część teoretyków rezyliencji zgadza się, iż jest to koncepcja skupiająca się na szeroko rozumianych mechanizmach łagodzenia negatywnych konsekwencji kryzysów, nadal istnieją rozbieżności co do interpretacji pożądanego modelu rezyliencji, jej istoty i zasady przewodniej (Walsh-Dilley, Wolford, 2015). W tym aspekcie, literatura wskazuje na dwa główne, choć nie jedyne, typy tej koncepcji. Z jednej strony, przedstawia się rezyliencję opartą na absorbowaniu szoków i względnie szybkim „odbiciu się” 
systemu do jego oryginalnego kształtu, przy jak najszybszym odbudowaniu kluczowych zasobów i przywróceniu funkcjonalności (tzw. „model odbicia” się lub ang. bounce back) (Gruszczak, 2016, s. 9). Z drugiej strony, rezyliencja ujmowana jest w kategoriach długotrwałego procesu adaptacyjnego, w którym system radzi sobie z kryzysowymi sytuacjami, ucząc się na swoich błędach i dostosowując swoje części składowe do nowej rzeczywistości (tzw. model adaptacyjny).

Handmer i Dovers, oraz później Bourbeau, proponują wprowadzenie tak zwanego rezyliencyzmu jako ramy konceptualnej, pozwalającej na zestawienie poszczególnych typów rezyliencji i lepsze zrozumienie różnorodnych metod utrzymania ciągłości funkcjonowania systemów, jak i ich ewentualnej transformacji w obliczu nieuchronnych kryzysów (Bourbeau, 2013; Handmer, Dovers, 1996). Rezyliencyzm przewiduje trzy, często przenikające się nawzajem, typy skupione na utrzymaniu (ang. maintnance), marginalnej adaptacji (ang. marginality) oraz odnowieniu (ang. renewal) - w literaturze tego typu rozróżnienie także określane jest jako rezyliencja MMR (Bourbeau, 2013; patrz: tabela 1).

Podejście mające na celu „utrzymanie” określonego systemu, koncentruje się na wypracowaniu w określonym systemie swoistej sprężystości, która pozwoli na absorbcję wszelkiego rodzaju szoków (np. ataku terrorystycznego), ale równocześnie umożliwi "odbicie się" do swojego oryginalnego kształtu po ustaniu kryzysu (Bourbeau, 2013, s. 10). „Utrzymanie” nie przewiduje ,przejścia do alternatywnego reżimu” i zwraca wyjątkową uwagę na „stopień zakłóceń, jakie system może wytrzymać i nadal powracać do swojej poprzedniej równowagi" (Methmann, Oels, 2015, s. 54). W tej perspektywie wszystkie zasoby i energia są skoncentrowane na instrumentach, które pozwalają utrzymać status quo systemu, podtrzymując jego podstawową strukturę, relacje i funkcje. Bourbeau zauważa, że odporność poprzez utrzymanie jest z natury zorientowana na dokładną identyfikację zagrożeń i badanie natury przewlekłych kryzysów, w celu „lepszego uzasadnienia konieczności wdrożenia środków w celu utrzymania status quo wobec zmian wywołanych przez niepożądane zdarzenia" (Bourbeau, 2015, s. 177). Podmioty odpowiedzialne za wprowadzanie rezyliencji będą dążyć do osiągnięcia bezwzględnej odporności na wszelkie zmiany, nawet te, które mogłyby potencjalnie pomóc w radzeniu sobie z zaistniałym kryzysem (Coaffee, Fussey, 2015, s. 91-92). Tym samym, będą charakteryzować się dużym stopniem ostrożności, raczej powielając rozwiązania innych, aniżeli polegać na własnej innowacyjności.

Podejście opierające się na „marginalnej adaptacji” dopuszcza łagodzenie negatywnych skutków kryzysu poprzez wprowadzanie zmian na marginesie systemów społeczno-politycznych, bez podważania ich podstawowych cech i funkcjonalności (Bourbeau, 2013, s. 14). W tym ujęciu, domyślne mechanizmy reagowania kryzysowego nadal opierają się na istniejących politykach czy normach, lecz w większym stopniu dopuszczają rozwiązania o charakterze oddolnym i innowacyjnym. W przeciwieństwie do ,utrzymania", konsekwencje nadchodzących wydarzeń są często postrzegane jako mniej dramatyczne lub groźne, ale wciąż na tyle niebezpieczne, aby wymusić zniekształcenie systemu (Bourbeau, 2015, s. 180). Jak zauważają Dunn Cavelty i in., „marginalna adaptacja odzwierciedla w jaki sposób dany aktor potrafi uczyć się na własnych błędach i umiejętnie wprowadzać rozwiązania, które historycznie sprawdzały się w określnym kontekście społeczno-politycznym" (np. w trakcie wojny, wielkich katastrof naturalnych) (Dunn 
Cavelty i in., 2015, s. 7). W tym przypadku, jedną z istotniejszych cech tego typu rezyliencji jest umiejętność innowacyjnego rozwiązywania zaistniałych problemów oraz samoorganizowanie się społeczeństwa w sytuacjach, które wymagają szybkiego uzupełniania określonych usług i zadań publicznych.

Trzeci rodzaj rezyliencji koncentruje się na tak zwanym „odnowieniu” lub „transformacji" podstawowych paradygmatów funkcjonowania określonego systemu, o ile będzie tego wymagała sytuacja kryzysowa. Perspektywa transformacyjna uzależnia stopień rezyliencji od poziomu innowacyjności i otwartości na zmiany w określonym systemie, polegającej na opracowywaniu i wprowadzaniu nowych sposobów myślenia o porządku społecznym, politycznym czy ekonomicznym (Bourbeau, 2015, s. 182). Tak rozumiana rezyliencja polega nie tylko na wypracowaniu odporności na zakłócenia, ale także na umiejętności stabilnej reorganizacji całego systemu i wyborze nowych trajektorii dla jego funkcjonowania i dalszego rozwoju (Grove, 2013). Podobnie jak w innych podejściach, konsekwencje kryzysu przedstawiane są jako groźne i tragiczne, ale zamiast promować opór wobec zmian, podejście transformacyjne przedstawia perspektywę głębokich reform jako coś ,normalnego”, a nawet nieuniknionego w dobie przewlekłych kryzysów (Chandler, 2014, s. 108). Nie oznacza to, że „odnowienie” wymaga przekonfigurowania całego systemu na nowo po każdym kryzysie, ale promuje podejście do tworzenia polityk publicznych oparte na dużej tolerancji na zmiany, bazujące na szerokim dialogu ze środowiskami naukowymi i eksperckimi. W związku z tym, badacze promujący „odnowienie” często postrzegają tragiczne wydarzenia jako okazję do reformy nieefektywnych i niewydolnych struktur społecznych, politycznych czy gospodarczych, w ten sposób wykorzystując wszelkie kryzysy do wprowadzenia potencjalnie pozytywnych zmian w społeczeństwie (Bourbeau, 2013; Folke i in., 2010). Poniższa tabela proponuje zestawienie wyżej omówionych typów rezyliencji w kontekście nauk o bezpieczeństwie.

Tabela 1

\section{Rezyliencyzm}

\begin{tabular}{|c|c|c|c|}
\hline & Utrzymanie & Marginalna adaptacja & Odnowa/transformacja \\
\hline 1 & 2 & 3 & 4 \\
\hline Orientacja na & Utrzymanie status quo & $\begin{array}{l}\text { Utrzymanie podstawowych } \\
\text { cech systemu, równocześnie } \\
\text { pozwalając na ograniczone } \\
\text { zmiany na jego peryferiach }\end{array}$ & $\begin{array}{l}\text { Pozytywna } \\
\text { systemu }\end{array}$ \\
\hline $\begin{array}{l}\text { Ocena środowi- } \\
\text { ska bezpieczeń- } \\
\text { stwa }\end{array}$ & $\begin{array}{ll}\text { Naznaczone } & \text { podwyższo- } \\
\text { nym ryzykiem } & \text { występowa- } \\
\text { nia poważnych } & \text { kryzysów, } \\
\text { uzasadniających } & \text { przekiero- } \\
\text { wanie } & \text { znacznych } \\
\text { i energii w celu utrzymano } \\
\text { najwrażliwszych elementów } \\
\text { systemu i zachowania jego } \\
\text { podstawowych cech i funk- } \\
\text { cjonalności }\end{array}$ & $\begin{array}{l}\text { Naznaczone podwyższonym } \\
\text { ryzykiem występowania po- } \\
\text { ważnych kryzysów, lecz z per- } \\
\text { spektywą na wyciągnięcie } \\
\text { wniosków, adaptację i lepsze } \\
\text { przygotowanie na niepewną } \\
\text { przyszłość }\end{array}$ & $\begin{array}{l}\text { Naznaczone podwyższonym } \\
\text { ryzykiem występowania } \\
\text { poważnych kryzysów, lecz } \\
\text { z perspektywą na pozytywną } \\
\text { zmianę systemu wynikającą } \\
\text { z sytuacji kryzysowej }\end{array}$ \\
\hline $\begin{array}{l}\text { Ocena zakłóceń } \\
\text { wynikających } \\
\text { z kryzysów }\end{array}$ & $\begin{array}{l}\text { Ściśle negatywne, szkodliwe } \\
\text { dla systemu }\end{array}$ & $\begin{array}{l}\text { Mniej dramatyczne, bardziej } \\
\text { znane }\end{array}$ & $\begin{array}{l}\text { Niebezpieczne, lecz „nie ma } \\
\text { tego złego, co by na dobre } \\
\text { nie wyszło" }\end{array}$ \\
\hline
\end{tabular}




\begin{tabular}{|c|c|c|c|}
\hline 1 & 2 & 3 & 4 \\
\hline \begin{tabular}{|l|} 
Zalecane strate- \\
gie działań
\end{tabular} & $\begin{array}{l}\text { Identyfikacja wrażliwych } \\
\text { podsystemów i wzmocnie- } \\
\text { nie ich poprzez przekiero- } \\
\text { wanie zasobów, najczęściej } \\
\text { z bardziej niezawodnych } \\
\text { podsystemów } \\
\text { Rozwijanie systemów i tech- } \\
\text { nologii wczesnego ostrzega- } \\
\text { nia i gotowości } \\
\text { Bazowanie na istniejących } \\
\text { rozwiązaniach z zakresu za- } \\
\text { rząanzania kryzysami i bez- } \\
\text { pieczeństwem } \\
\text { Rozwijanie technologii } \\
\text { i rozwiązań bazujących na } \\
\text { zwiększeniu odporności sys- } \\
\text { temu }\end{array}$ & $\begin{array}{l}\text { Identyfikacja wrażliwych sys- } \\
\text { temów z perspektywą ich ada- } \\
\text { ptacji do warunków kryzyso- } \\
\text { wych } \\
\text { Rozwijanie innowacyjnych, } \\
\text { oddolnych, wspólnotowych } \\
\text { mechanizmów zorientowanych } \\
\text { na łagodzenie negatywnych } \\
\text { konsekwencji kryzysów } \\
\text { Inwestowanie w edukację, na- } \\
\text { ukę innowacyjność, rozwijanie } \\
\text { świadomości o aktualnych i po- } \\
\text { tencjalnych kryzysach } \\
\text { Inwestowanie w inicjatywy } \\
\text { mające na celu zwiększyć go- } \\
\text { towość na kryzysy, spójność } \\
\text { społeczną (np. społeczeństwo } \\
\text { obywatelskie, wolontariat) }\end{array}$ & $\begin{array}{l}\text { Identyfikacja kluczowych } \\
\text { elementów systemu, które są } \\
\text { najbardziej wrażliwe i mają } \\
\text { największą szansę na pozy- } \\
\text { tywną reformę w sytuacjach } \\
\text { kryzysowych } \\
\text { Rozwijanie systemu edukacji } \\
\text { na wszystkich poziomach, } \\
\text { szczególnie uwzględniając } \\
\text { debatę nad negatywnymi } \\
\text { konsekwencjami globalizacji } \\
\text { czy zmian klimatu, inwesto- } \\
\text { wanie w przyszłe przywódz- } \\
\text { two i społeczną akceptację } \\
\text { fundamentalnych zmian } \\
\text { w obliczu takiej konieczno- } \\
\text { ści }\end{array}$ \\
\hline
\end{tabular}

Źródło: Zestawienie własne.

Tak ujęty rezyliencyzm nie zamyka katalogu rozumienia rezyliencji, raczej wprowadza jego idealne typy, które mogą, ale nie muszą, być odzwierciedlone w konkretnych strategiach bezpieczeństwa czy zarządzania kryzysowego. W istocie coraz większa część badaczy wskazuje, że nie istnieje jedyny słuszny model rezyliencji, a przyjęte mechanizmy łagodzenia konsekwencji kryzysów zawsze będą się w jakimś stopniu przenikać i różnicować w zależności od incydentu, jego charakteru czy intensywności (Walsh-Dilley, Wolford, 2015). Sposób rozumienia rezyliencji będzie zawsze w pewnym zakresie kształtowany przez doświadczenia przeszłych kryzysów, wiedzę lokalną, kulturę, strukturę społeczną i polityczną, kulturę organizacyjną, dostęp do zasobów materialnych i wiele czynników, które wpływają na postrzeganie zagrożeń i sposób radzenia sobie w trudnych, kryzysowych sytuacjach.

\section{Konkluzje i uwagi końcowe}

Rezyliencja jest powszechnie uznawana za najnowsze podejście w naukach o bezpieczeństwie, przedstawiające alternatywny sposób myślenia o niepewności i temporalności zagrożeń, odpowiedzialności za bezpieczeństwo czy podmiotowości w systemie bezpieczeństwa. Istotnym wątkiem $\mathrm{w}$ dyskusji nad rezyliencją jest zmiana postrzegania roli struktur lokalnych, oddolnych inicjatyw, edukacji, nauki i wielu innych elementów, które w różnym stopniu przekładają się na ciągłe zwiększanie odporności i umiejętności adaptacyjnych jednostek i grup społecznych w obliczu kryzysów. Bez wątpienia, rezyliencja jest koncepcją ważną i konceptualnie atrakcyjną. Otwiera bardzo istotne wątki w dyskusji nad potencjalnymi korektami paradygmatów bezpieczeństwa, uwzględniając możliwości wprowadzenia jego subsydiarności i rozproszenia w obliczu przewlekłych kryzysów. Koncepcji tej nie należy jednak postrzegać bezkrytycznie. 
Rezyliencja nie stanowi panaceum na bolączki współczesnego bezpieczeństwa i wielu badaczy odnosi się do niej w sposób ostrożny, wskazując na jej problematyczne aspekty w ujęciu teoretycznym, jak i praktycznym (Estêvão i in., 2017; Manyena, 2006). Jeżeli rezyliencja stanowi utrzymanie pewnego pożądanego „stanu normalności”, należy przede wszystkim osiągnąć pewien konsens społeczny co do tego, czym jest owa „,normalność”. Nawet jeżeli udałoby osiągnąc porozumienie w tej kwestii, co jest wyzwaniem samym w sobie, następnym krokiem byłoby wypracowanie odpowiedzi na pytania w jaki sposób ten „stan normalności” miałby nabyć rezyliencję i jak miałaby ona być weryfikowana? (Cavelty, Prior, 2013). Aktualnie nie istnieje żadna powszechnie uznana metodologia, która pozwoliłaby zmierzyć poziom rezyliencji określonego systemu, a tym samym kontrolować trajektorię i postępy polityk rezyliencyjnych (Estêvão i in., 2017).

Inne krytyczne argumenty skupiają się na społecznym wymiarze rezyliencji. Niektóre interpretacje rezyliencji bazują na przeświadczeniu, iż istnieje możliwość wypracowania jakiejś formy „idealnego społeczeństwa”, gdzie zaufanie, solidarność czy kapitał społeczny w sposób niemalże automatyczny przełożą się na możliwości absorpcyjne społeczeństwa i szybko pozwolą mu zaadaptować się do nowych (post)kryzysowych warunków (Manyena, 2006). Wypracowanie nawet zalążkowej rezyliencji w państwach już rozwiniętych jest co najmniej problematyczne, na co wskazują przykłady Singapuru czy Wielkiej Brytanii (Cavelty, Prior, 2013, s. 4). Wiąże się to nie tylko z potrzebą inwestycji znacznych środków i energii w najsłabsze ogniwa systemu, ale także z potrzebą ciągłego utrwalania i kultywowania rezyliencyjnych postaw i cech na wszystkich poziomach bezpieczeństwa. Przy dynamicznie zmieniającej się sytuacji politycznej, faworyzowaniu w budżetach narodowych tradycyjnych i militarnych polityk bezpieczeństwa, powszechne i ciągłe utrzymanie polityki rezyliencyjnej, przede wszystkim w kontekście inicjatyw lokalnych i edukacji, jest nie lada wyzwaniem.

Należy także pamiętać, że wszelkie próby utrzymania wydolności systemu w sytuacji kryzysowej wiążą się niejednokrotnie z wyrzeczeniami, takimi jak obniżki pensji, bezrobocie związane z obniżeniem wzrostu gospodarczego, ograniczony dostęp do usług publicznych w tym ochrony zdrowia. Polityka rezyliencyjna, przede wszystkim w wymiarze adaptacyjnym, może generować frustracje i napięcia społeczne, zwłaszcza w sytuacji, dysproporcji strat ponoszonych przez różne części społeczeństwa (Kaufmann, 2016). Może to prowadzić do głębszej destabilizacji systemu i eskalacji negatywnych konsekwencji kryzysu. Dlatego polityki rezyliencyjne muszą być prowadzone z niezwykłym wyczuciem społecznym, odpowiedzialnością oraz dążyć do równego i sprawiedliwego rozłożenia napięć spowodowanych przez kryzys.

Bynajmniej nie należy odbierać tych uwag krytycznych za negowanie podejścia rezyliencyjnego. Wręcz przeciwnie, wyżej zarysowany przykład krytyki rezyliencji, powinien stanowić wyzwanie badawcze i wręcz zachętę do dalszych rozważań nad tym paradygmatem. Jak wskazuje Chandler, nadal istnieje spory deficyt badań nad rezyliencją zarówno w wymiarze społecznym, jak i stricte politycznym (Chandler, 2020). Współczesny dyskurs rezyliencyjny w dużej mierze opiera się na analizie konkretnych przypadków, kryzysów i społeczności, które próbują oprzeć się negatywnym skutkom tychże kryzysów. W tym zakresie badania nad Polską oraz innymi krajami regionu Europy Środkowej i Wschodniej, reprezentują poważną pogłębiającą się lukę badawczą. Kryzys COVID-19 i jego konsekwencje z całą pewnością będą stanowić spore wyzywanie 
dla badaczy nauk społecznych. Należy jednak spojrzeć na nie także jako pewną szansę na uzupełnienie tej luki i skupienie się na rezyliencyjnych aspektach bezpieczeństwa w Polsce oraz innych krajach regionu. Takie podejście, wzmocnione przez uwzględnienie specyfiki i istotnych cech państw Europy Środkowo-Wschodniej pozwoliłoby wzbogacić istniejące modele teoretyczne i zgłębić znaczenie i zastosowanie rezyliencji jako paradygmatu bezpieczeństwa w czasach przewlekłych kryzysów.

\section{Bibliografia}

Adey P., Anderson B. (2012), Anticipating emergencies: Technologies of preparedness and the matter of security, „Security Dialogue”, vol. 43, nr 2.

Aldrich D. P., Meyer M. A. (2015), Social Capital and Community Resilience, „American Behavioral Scientist", vol. 59, $\mathrm{nr} 2$.

Aradau C., Lobo-Guerrero L., van Munster R. (2008), Security, Technologies of Risk, and the Political: Guest Editors'Introduction, „Security Dialogue”, vol. 39, nr 2-3.

Aradau C., van Munste R. (2011), Politics of Catastrophe. Genealogies of the Unknown, Routledge, London-New York.

Berkes F., Ross H. (2013), Community Resilience: Toward an Integrated Approach, „Society \& Natural Resources", vol. 26, nr 1.

Bonanno G. A. (2004), Loss, Trauma, and Human Resilience: Have We Underestimated the Human Capacity to Thrive After Extremely Aversive Events?, „American Psychologist”, vol. 59, nr 1.

Bourbeau P. (2013), Resiliencism: premises and promises in securitization research, „Resilience”, vol. $1, \mathrm{nr} 1$.

Bourbeau P. (2015), Resiliencism and security studies: initiating a dialogue, w: Contesting Security: Strategies and Logics, red. T. Balzacq, Routledge, London-New York.

Brassett J., Croft S., Vaughan-Williams N. (2013), Introduction: An Agenda for Resilience Research in Politics and International Relations, „Politics”, vol. 33, nr 4.

Brassett J., Vaughan-Williams N. (2015), Security and the performative politics of resilience: Critical infrastructure protection and humanitarian emergency preparedness, „Security Dialogue”, vol. 46, nr 1.

Cavelty M. D., Prior T. (2013), Resilience in Security Policy: Present and Future, „CSS Analysis in Security Policy", nr 142.

Chandler D. (2014), Resilience : the governance of complexity, Routledge, London-New York.

Chandler D. (2020), Security through societal resilience: Contemporary challenges in the Anthropocene, „Contemporary Security Policy”, vol. 41, nr 2.

Coaffee J., Fussey P. (2015), Constructing resilience through security and surveillance: The politics, practices and tensions of security-driven resilience, ,Security Dialogue”, vol. 46, nr 1.

Dacko M., Dacko A. (2018), Studia nad rozwojem obszarów wiejskich - od paradygmatu wzrostu do rezyliencji, Wieś i Rolnictwo, vol. 179, nr 2.

Drobniak A. (2018), Programowanie rezyliencji miejskiej - przykład dzielnicy Załęże w Katowicach, „Prace Naukowe Uniwersytetu Ekonomicznego we Wrocławiu”, nr 502.

Dunn Cavelty M., Kaufmann M., Søby Kristensen K. (2015), Resilience and (in)security: Practices, subjects, temporalities, „Security Dialogue”, vol. 46, nr 1.

Estêvão P., Calado A., Capucha L. (2017), Resilience: Moving from a "heroic" notion to a sociological concept, „Sociologia, Problemas e Praticas”, nr 85.

Fletcher D., Sarkar M. (2013), Psychological Resilience, „European Psychologist”, vol. 18, nr 1. 
Folke C., Carpenter S. R., Walker B., Scheffer M., Chapin T., Rockström J. (2010), Resilience thinking: Integrating resilience, adaptability and transformability, „Ecology and Society”, vol. 15, nr 4.

Grove K. (2013), On resilience politics: from transformation to subversion, „Resilience”, vol. 1, nr 2.

Gruszczak A. (2016), Resilience and Mitigation in Security Management: Concepts and Concerns, „Forum Scientiae Oeconomia”, vol. 4, nr 1.

Grzegorzewska I. (2013), Odporność psychiczna dzieci alkoholików, Scholar, Kraków.

Gunderson L. H. (2000), Ecological Resilience - In Theory and Application, „Annual Review of Ecology and Systematics", vol. 31, nr 1.

Handmer J. W., Dovers S. R. (1996), A Typology of Resilience: Rethinking Institutions for Sustainable Development, „Industrial \& Environmental Crisis Quarterly”, vol. 9, nr 4.

Harff B., Gurr T. R. (1998), Systematic Early Warning of Humanitarian Emergencies, „Journal of Peace Research", vol. 35, nr 5.

Holling C. S. (1973), Resilience and Stability of Ecological Systems, „Annual Review of Ecology and Systematics", vol. 4, nr 1.

Juncos A. E. (2017), Resilience as the new EU foreign policy paradigm: a pragmatist turn?, „European Security", vol. 26, nr 1.

Kaufmann M. (2013), Emergent self-organisation in emergencies: resilience rationales in interconnected societies, ,Resilience”, vol. 1, nr 1.

Kaufmann M. (2016), Exercising emergencies: Resilience, affect and acting out security, „Security Dialogue", vol. 47, nr 2.

Lucini B. (2014), Disaster Resilience from a Sociological Perspective: Exploring Three Italian Earthquakes as Models for Disaster Resilience Planning, Springer, Cham.

Lund Petersen K. (2008), Terrorism: When Risk Meets Security, „Alternatives: Global, Local, Political", vol. 33, $\mathrm{nr} 2$.

Manyena S. B. (2006), The concept of resilience revisited, „Disasters”, vol. 30, $\mathrm{nr} 4$.

Methmann C., Oels A. (2015), From "fearing” to "empowering” climate refugees: Governing climateinduced migration in the name of resilience, ,Security Dialogue”, vol. 46, nr 1.

Niemann A., Schmidthäussler N. (2014), The Logic of EU Policy-Making on (Irregular) Migration: Securitisation or Risk?, „Mainz Papers on International and European Politics”, nr 6.

Norris F. H., Stevens S. P., Pfefferbaum B., Wyche K. F., Pfefferbaum R. L. (2008), Community resilience as a metaphor, theory, set of capacities, and strategy for disaster readiness, „American Journal of Community Psychology", vol. 41, nr 1-2.

Olsson L., Jerneck A., Thoren H., Persson J., O’Byrne D. (2015), Why resilience is unappealing to social science: Theoretical and empirical investigations of the scientific use of resilience, ,Science Advances", vol. 1, nr 4.

Paton D., Johnston D. (2001), Disasters and communities: Vulnerability, resilience and preparedness, „Disaster Prevention and Management: An International Journal”, vol. 10, nr 4.

Prior T. (2017), NATO : Pushing Boundaries for Resilience, „CSS Analyses in Security Policy”, nr 213.

Pyka R. (2018), Kultura jako czynnik miejskiej rezyliencji na przyktadzie dawnych miast przemystowych należacych do Sieci Miast Kreatywnych UNESCO. Przypadek dwóch miast: Katowice i Saint-Étienne, „Kultura i Społeczeństwo”, vol. 62, nr 3.

Stepka M. (2016), Assessing risks. A critical perspective on conflict early warning systems, „Studies in Politics and Society", vol. 14, $\mathrm{nr} 4$.

Walsh-Dilley M., Wolford W. (2015), (Un)Defining resilience: subjective understandings of 'resilience' from the field, „Resilience”, vol. 3, nr 3.

Wildavsky A. (1988), Searching for Safety, Transaction Publishers, New Brunswick.

Zebrowski C. (2013), The nature of resilience, „Resilience”, vol. 1, nr. 3. 
Zebrowski C. (2015), The Value of Resilience: Securing Life in the Twenty-First Century, Routledge, London-New York.

\title{
Resilience - searching for security in times of protracted crises
}

\begin{abstract}
Summary
In times of protracted and periodic crises such as epidemics, increased migratory flows and climate change, resilience has become an attractive and increasingly relevant approach to security. It opens new avenues of inquiry about crisis management introducing a refreshed perspective on diffusion of responsibility or temporality of security. Resilience is understood as an ensemble of societal and individual mechanisms for dealing with crisis situations, adaptive capabilities and "bouncing back" to a form of normal state after a period of crisis. This article discusses the complexity of resilience, outlining a synthesis of the current understanding of this concept from political and security perspectives, and promoting resiliencism as a promising analytical framework. In this way, the article calls for more significant inclusion of resilience in studies on Polish security practices and discourses.
\end{abstract}

Key words: resilience, risk, security, crisis management, COVID-19 
